\title{
A new species of predaceous midge in the Patagonian genus Austrosphaeromias with a redescription of A. chilensis (Diptera, Ceratopogonidae)
}

\author{
Gustavo R. Spinelli' , María M. Ronderos' \& William L. Grogan Jr. ${ }^{2}$
}

\author{
1. División Entomología, Museo de La Plata - CEPAVE-CCT-CONICET, Paseo del Bosque s/n, 1900 La Plata, Argentina. \\ (spinelli@fcnym.unlp.edu.ar; ronderos@fcnym.unlp.edu.ar) \\ 2. Florida State Collection of Arthropods, Florida Department of Agriculture and Consumer Services, Gainesville, Florida 32614, U.S.A. (William.Grogan@freshfromflorida.com)
}

\begin{abstract}
A new species of predaceous midge, Austrosphaeromias setosa sp. nov., is described and illustrated from adult males and females collected in the Patagonian-Andean region of Argentina and Chile. Based on examination of the type species of Austrosphaeromias Spinelli, 1997 and recently collected specimens from near the type-locality, the female and previously unknown male of Austrosphaeromias chilensis (Ingram \& Macfie, 1931) are also described and illustrated. Descriptions are accompanied by color photographs and illustrations of key features of females and males of both species. We also provide a key to adult females and males of the four species of Austrosphaeromias.
\end{abstract}

KEYWORDS. Ceratopogoninae, Sphaeromiini, Neotropical, Taxonomy.

\begin{abstract}
RESUMEN. Una especie nueva de mosquita predadora del género Patagónico Austrosphaeromias con la redescripción de $A$. chilensis (Diptera, Ceratopogonidae). Se describe e ilustra una nueva especie de mosquita predadora, Austrosphaeromias setosa sp. nov., a partir de adultos macho y hembra colectados en la región Andino-patagónica de Argentina y Chile. Además, sobre la base del examen de la especie tipo de Austrosphaeromias Spinelli, 1997 y de ejemplares recientemente colectados en las proximidades de la localidad tipo, se describen e ilustran la hembra de Austrosphaeromias chilensis (Ingram \& Macfie, 1931) y el macho, previamente desconocido. Las descripciones son acompañadas por fotografías a color e ilustraciones de los caracteres clave de hembras y machos de ambas especies. Se brinda, además, una clave para adultos hembra y macho de las cuatro especies de Austrosphaeromias.
\end{abstract}

PALABRAS CLAVE. Ceratopogoninae, Sphaeromiini, Neotropical, Taxonomía.

The predaceous midge genus Austrosphaeromias Spinelli (Diptera: Ceratopogonidae, Sphaeromiini) was proposed by Sinelli (1996) for two species from Argentine and Chilean Patagonia: Austrosphaeromias wirthi Spinelli, 1996, known only from the type-locality in southern Argentina, and Palpomyia apricans Ingram \& Macfie, 1931. Subsequently, Spinelli et al. (2009) assigned Palpomyia chilensis Ingram \& Macfie, 1931 to Austrosphaeromias, and indicated that another undescribed species was in the entomological collection of the Museo de La Plata, Argentina (MLPA).

During our study of Patagonian predaceous midges in the genus Palpomyia Meigen (SPINelli et al., 2009), we initially considered the latter two above species as members of this genus because their uncanny resemblance to species of the distincta group. For example, both species possessed greatly swollen fore femur with numerous ventral spines, and females had short, equal-sized claws and small, ovoid subequal-sized spermathecae (GROGAN \& WiRTH, 1979). However, males lacked a mesobasal tubercle on their gonocoxites as well as a broadly triangular apex on their aedeagus, and females lacked a pair of soft setose lobes on the anterolateral margins of sternite 8 and a distal hyaline plate on that structure (SPINELLI et al., 2009). In addition, sternite 8 of females of the Palpomyia distincta group features a separate proximal portion with scattered setae, whereas both species in question possessed a closely approximated group of more coarse setae.
We eventually determined that both of these species were members of the genus Austrosphaeromias. Herein we describe and illustrate a new species of Austrosphaeromias as well as the female and previously unknown male of $A$. chilensis.

\section{MATERIAL AND METHODS}

Specimens were collected with Malaise and light traps, or, by sweeping flowers and other vegetation along the margins of rivers, streams and lakes. All specimens were preserved in $70 \%$ ethanol and subsequently cleared, dissected and mounted onto microscope slides in Canada balsam for more detailed study. They were examined and measured at 40-400x with a binocular compound microscope and drawings of diagnostic characters were prepared with the aid of an attached camera lucida. Photomicrographs were taken with a digital camera attached to a microscope.

The holotype and paratypes of our new species are deposited in the MLPA, and paratypes as available are deposited in the U. S. National Museum of Natural History, Smithsonian Institution, Washington, D. C. (USNM); the Natural History Museum, London (BMNH); the Canadian National Collection of Insects, Ottawa (CNCI); and the Florida State Collection of Arthropods, Gainesville (FSCA). Terminology of morphological structures follows those in the Manual of Central American Diptera (Brown et al., 2009). 


\section{RESULTS}

Key to adults of Austrosphaeromias (the male of $A$. wirthi is unknown)

1. Female .. 2 Male 5

2. Tarsomeres 5 with stout ventral setae; sternite 8 with tuft of 12-16 slender setae .................................. 3 Tarsomeres 5 without spines; sternite 8 with a pearshaped patch of 24-37 stouter setae ... A. setosa sp. nov.

3. Legs mostly dark brown, fore femur paler except extreme apex, mid and hind femora paler on basal $1 / 2$ or $1 / 3$, midportion of fore tibia slightly paler

A. apricans (Ingram \& Macfie) Legs yellowish or yellowish brown, apices of tibiae brown, femorotibial joints dark, tarsomeres 3-5 brown

4. Fore femur greatly swollen, $2.74-3.30 x$ longer than broad with 18-25 ventral spines

A. chilensis (Ingram \& Macfie)

Fore femur moderately swollen, 4.30-4.75x longer than broad, with 17-19 ventral spines ......... A. wirthi Spinelli

5. Distal flagellomeres greatly elongate, antennal ratio 1.011.04, flagellomere 11 2.07-2.19x longer than flagellomere 10 ... 6 Distal flagellomeres shorter, antennal ratio 0.57-0.75, flagellomere 11 1.46-1.65x longer than flagellomere 10 ... A. setosa sp. nov.

6. Gonostylus $0.66 x$ longer than gonocoxite, nearly straight to tip; aedeagus as long as basal breadth

A. chilensis (Ingram \& Macfie) Gonostylus shorter, deeply curved at tip; aedeagus elongate, $1.83 \mathrm{x}$ longer than basal breadth

A. apricans (Ingram \& Macfie)

\section{Austrosphaeromias chilensis (Ingram \& Macfie, 1931)}

(Figs 1-8, 17, 18)

Palpomyia chilensis Ingram \& MACFIE, 1931:218 (female; Chile); WIRTH, 1974:54 (cat.); Borkent \& Wirth, 1997:131 (cat.); Borkent \& SPINELli, 2000:63 (cat.; distr.); 2007:96 (cat.; distr.).

Austrosphaeromias chilensis: SPINELli et al., 2009:44 (comb.); BORKENT, 2014:144 (cat.).

Diagnosis. Female with legs mostly yellowish or yellowish brown, fore femur greatly swollen, tarsomeres 5 with 2-8 ventral setae and sternite 8 with tuft of 12-16 large coarse setae. Male legs coloration similar to female or with distal $1 / 3$ of femora and basal $1 / 3$ and narrow apex of tibiae brown, gonostylus nearly straight, 0.66 length of gonocoxite, and aedeagus as long as basal breadth.

Female. Head (Fig. 1) dark brown, clypeus slightly paler. Eyes separated for a distance equal to the diameter of 3 ommatidia. Antennal flagellum dark brown; flagellomeres 2-8 vasiform, moderately long; flagellomeres 9-13 greatly elongate; antennal ratio 1.52-1.64 (1.61, $\mathrm{n}=4)$. Palpus dark brown; segment 3 slightly shorter than $4+5$, with 3-7 capitate sensilla on mesal surface; palpal ratio 3.44-4.15 (3.79, $n=4)$. Mandible with 6-8 large inner teeth.

Thorax (Fig. 2) dark brown. Scutum with small anterior tubercle, sparsely covered with short slender setae, 3-4 stout supralar setae; scutellum with 4-6 stout and several smaller setae. Femora and tibiae yellowish or yellowish brown, apices of tibiae brown, femorotibial joints dark brown; tarsomeres 1-2 yellowish or yellowish brown, 3-5 brown; fore femur greatly swollen, 2.74-3.30x $(3.02, n=4)$ longer than broad, with $18-25$ ventral spines, ventral palisade setae in two rows on tarsomeres 1-2 of hind leg, in one row on tarsomere 1 of mid leg; tarsomeres 5 (Fig. 3) with 2-6 stout ventral setae; claws short, equalsized with moderately long basal teeth. Wing (Fig. 4) membrane moderately infuscated; anterior veins dark brown, posterior veins lighter brown; $\mathrm{M}$ sessile, distance between $r-m$ crossvein and base of vein $M_{2} 2.50(n=4) x$ length of $\mathrm{r}-\mathrm{m} ; 2^{\text {nd }}$ radial cell 2.00-2.50 $(2.20, \mathrm{n}=4) \mathrm{x}$ longer than $1^{\text {st; }}$ wing length $2.34-2.94(2.64, n=4) \mathrm{mm}$, width 0.75-0.96 (0.86, $\mathrm{n}=4) \mathrm{mm}$; costal ratio 0.79-0.82 (0.80, $\mathrm{n}=4)$. Halter dark brown.

Abdomen. Dark brown. Genitalia as in Figs. 5, 17. Sternite 8 with anterior v-shaped tuft of 12-16 large setae; sternite 9 moderately sclerotized with pair of slender, curved anteriorly, anteromesally directed arms; sternite 10 moderately long, heart-shaped, with 6-7 pairs of large setae. Two ovoid, slightly unequal-sized spermathecae with short necks, measuring 70-86 $(76, \mathrm{n}=4)$ by $60-68 \mu$ $(62, n=4)$, and $64-70(66, n=4)$ by $50-60 \mu(55, n=4)$; and a rudimentary $3^{\text {rd }}$ spermatheca, that is well developed in one specimen.

Male: similar to female, but smaller, with the following notable sexual differences: head (Fig. 6) with flagellomeres 1-10 with long sensilla chaetica that comprise the moderately dense plume; flagellomere $112.07-2.19 x$ $(2.12, \mathrm{n}=3)$ longer than 10 ; antennal ratio (flagellomeres 1113/1-10) 1.01-1.04 (1.03, n=3). Coloration of legs similar to female except distal $1 / 3$ of femora and proximal $1 / 3$ of tibiae brown in some specimens; tarsomeres 5 without ventral setae; claws smaller, apices deeply bifid. Wing (Fig. 7) length 2.01-2.06 mm (2.04, $\mathrm{n}=3$ ), width 0.57$0.60 \mathrm{~mm}(0.59, \mathrm{n}=3)$; costal ratio $0.73-0.75(0.74, \mathrm{n}=3)$; $2^{\text {nd }}$ radial cell $1.64-1.90 x(1.76, n=3)$ longer than 1 st. Genitalia (Figs 8, 18-19): tergite 9 extending just below apices of gonocoxites, posterior margin rounded; cerci elongate, extending beyond apices of gonocoxites, with 2 pairs of setae, one pair elongate, 2nd pair shorter; sternite 9 moderately short with deep, rounded, posteromedian excavation, ventral membrane spiculate. Gonocoxite straight, twice as long as broad with pointed anteromesal protuberance; gonostylus 0.66 length of gonocoxite, nearly straight, distal half gradually tapering to a bluntly rounded tip. Parameres (Fig. 19) fused on extreme bases for a short distance, heavily sclerotized, with stout basal apodeme that is recurved $30^{\circ}$, apical portion folded dorsally with narrow rounded tip; distal portions slightly curved with expanded, rounded apices that are closely approximated. Aedeagus 

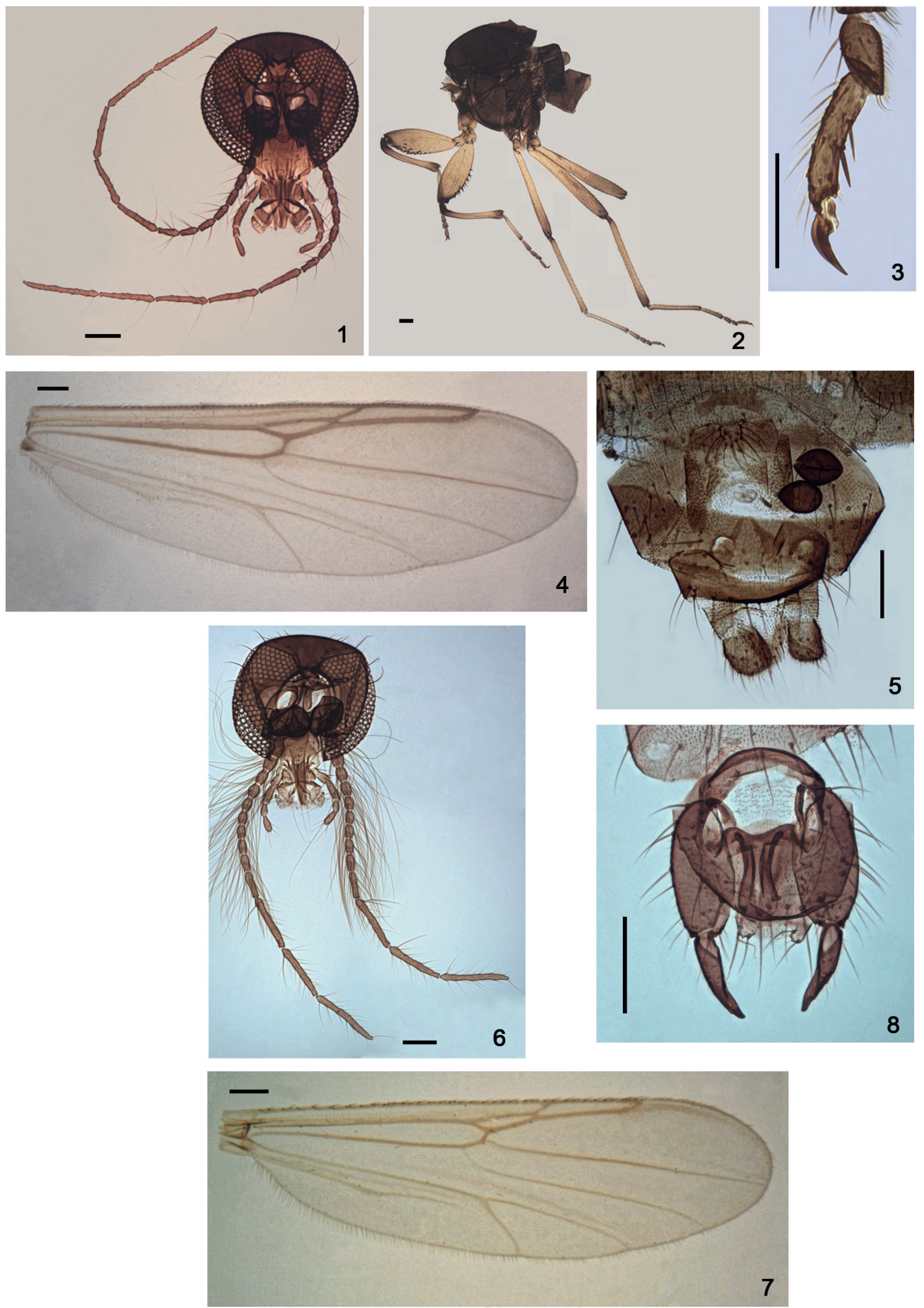

Figs 1-8. Austrosphaeromias chilensis (Ingram \& Macfie, 1931). 1-5, female, 6-8, male. 1, 6, head; 2, thorax; 3, tarsomeres 4-5 and claws; 4, 7, wing; 5, abdominal segments 7-10; 8, genitalia. Scale bars: $0.05 \mathrm{~mm}$.

(Fig. 18) triangular, slightly longer than broad; basal arm heavily sclerotized, straight to slightly recurved; basal arch extending 0.4 of total aedeagus length; distal portion lateral margins moderately sclerotized, main body and posterior margin more lightly sclerotized, narrowed distally with small bilobed apex, each lobe directed laterally. 

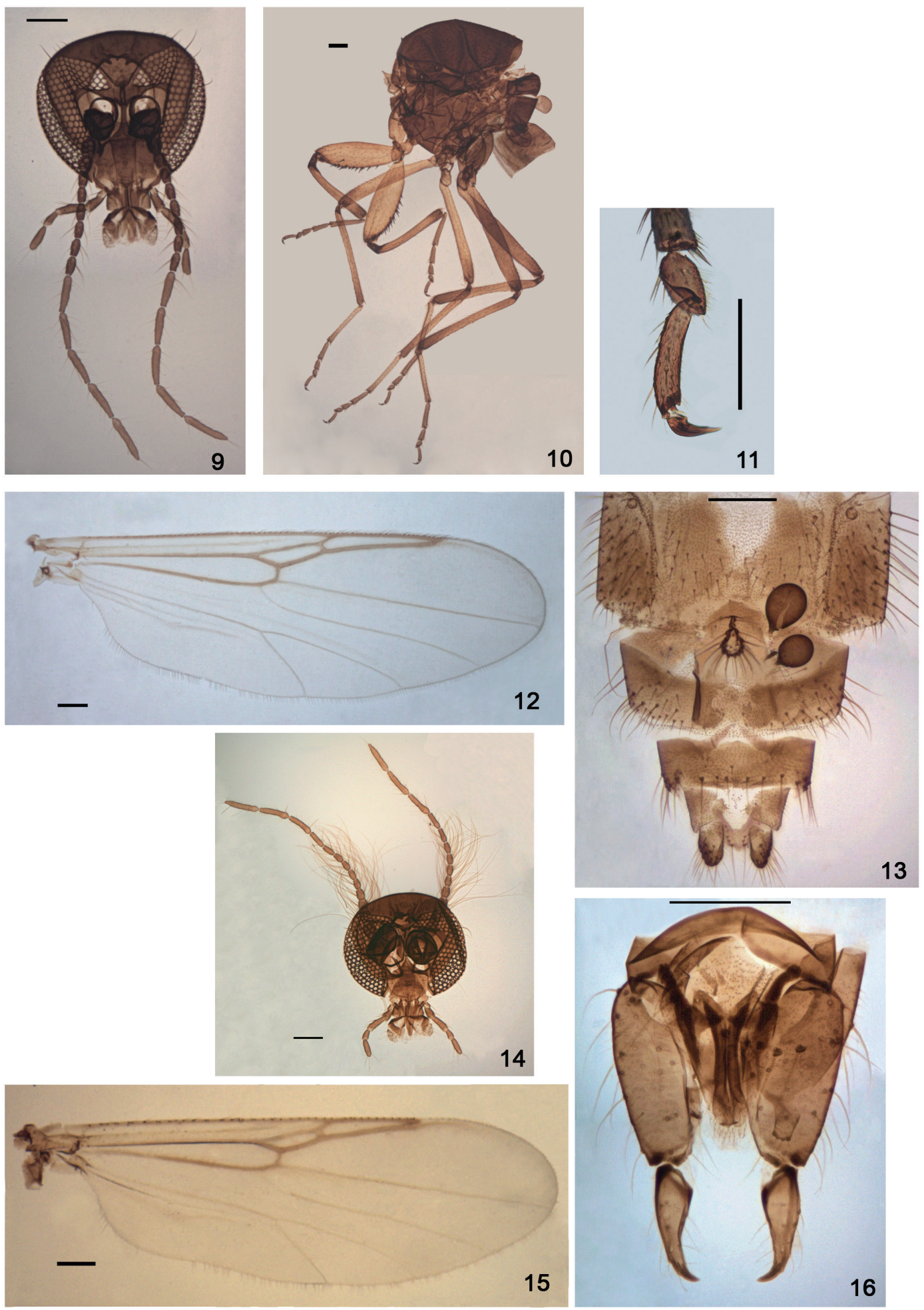

Figs 9-16. Austrosphaeromias setosa sp. nov. 9-13, female, 14-16, male. 9, 14, head; 10, thorax; 11, tarsomeres 4-5 and claws; 12, 15, wing; 13, abdominal segments $7-10 ; 16$, genitalia. Scale bars: $0.05 \mathrm{~mm}$.

Distribution. Argentina (western Neuquen province and Nahuel Huapi National Park); Chile (Llanquihue province).

Type material. Holotype $q$ : CHILE, Llanquihue: Ensenada, 14/15.XII.1926, F. \& W. Edwards (BMNH, examined).
Other material examined. ARGENTINA, Neuquen: Junin de los Andes, río Chimehuin, 17.I.2006, W. Grogan-G. Spinelli, sweep net, $3 \hat{\jmath}, 2$ ㅇ (MLPA); Parque Nacional Nahuel Huapi, río Manso medio, 41 ${ }^{\circ} 14^{\prime} 8.1^{\prime \prime} \mathrm{S}, 71^{\circ} 46^{\prime} 58.5^{\prime \prime} \mathrm{W}, 845$ m, 7.II/2.III.2007, F. Montes de Oca, Malaise trap, 9 (MLPA); same data except lago Gutiérrez, 20.I.2006, W. Grogan-G. Spinelli, ô, sweep net (MLPA); same data except río Guillelmo, 20.I.2006, W. Grogan-G. Spinelli, ơ (MLPA). 
Taxonomic discussion. Females of $A$. chilensis most closely resemble females of $A$. wirthi, but in the latter species the fore femur is only moderately swollen (4.30-4.75x longer than broad) and bears 17-19 ventral spines. The male of $A$. wirthi is unknown.

Austrosphaeromias chilensis is also similar to $A$. setosa sp. nov. However, the female of the latter species has shorter flagellomeres 9-13, tarsomeres 5 lack stout ventral setae, and the group of setae on the anterior portion of sternite 8 is very peculiar, pear-shaped. Males of $A$. setosa differ from males of $A$. chilensis in having a shorter antennal flagellum (antennal ratio 0.57-0.75), moderately long flagellomeres 11-13, an apically curved gonostylus, and a narrower aedeagus with a longer basal arch that extends 0.5 of its total length.

\section{Austrosphaeromias setosa Spinelli, Ronderos \& Grogan, sp. nov.}

(Figs. 9-16, 20-22)

Diagnosis. Female with tarsomeres 5 devoid of ventral stout setae and sternite 9 with a pear-shaped group of 24-37 stout setae. Male with a relatively short flagellum (antennal ratio, 0.57-0.75), flagellomeres 11-13 moderately long, flagellomere 11 1.46-1.65x longer than 10; a gonostylus that is apically curved; and a moderately narrow aedeagus with a long basal arch extending 0.5 of its total length.

Female. Head (Fig. 9) dark brown. Eyes separated for a distance equal to the diameter of 3-4 ommatidia. Antennal flagellum with flagellomeres 1-8 dark brown,
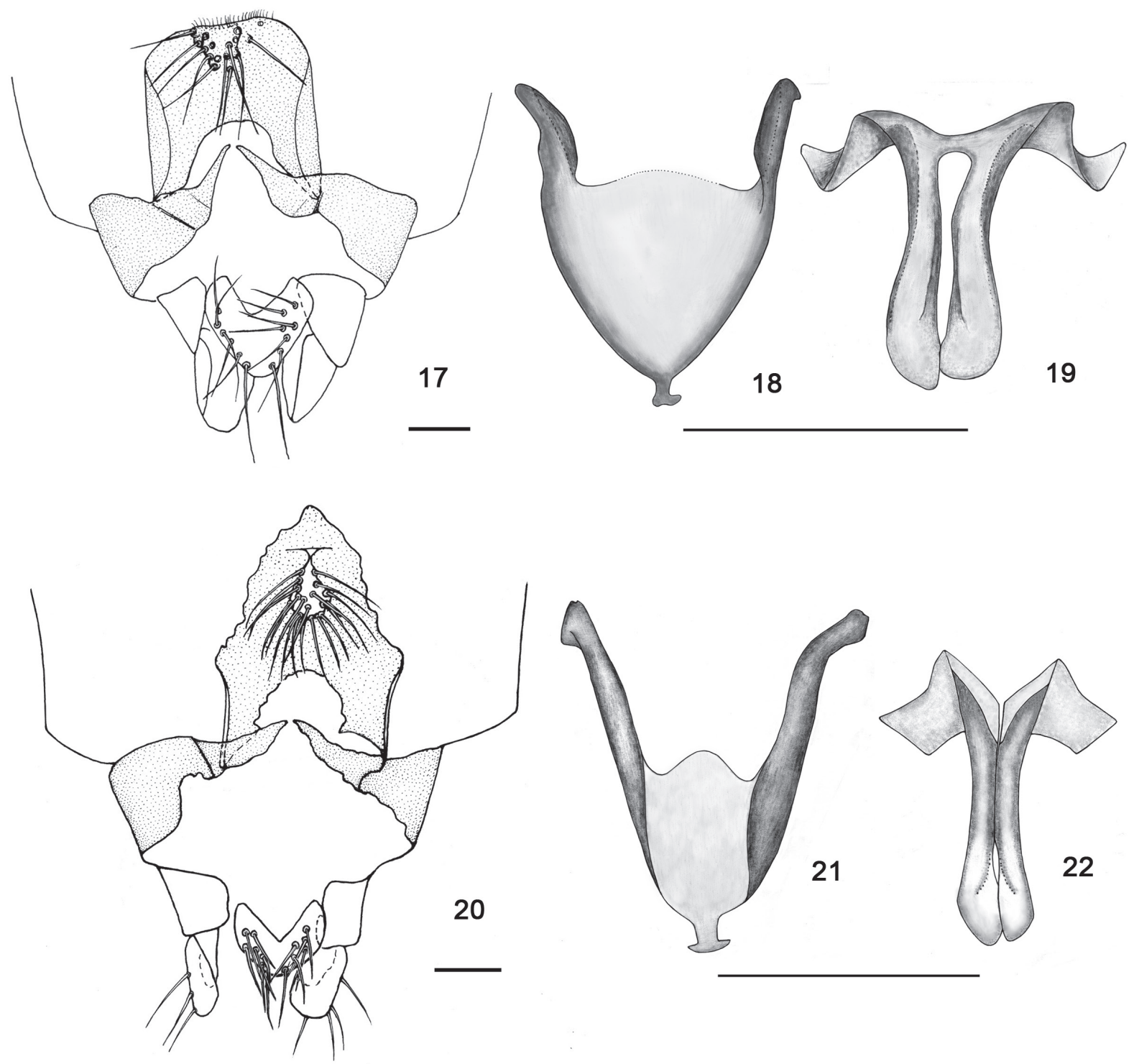

Figs 17-22. 17-19, Austrosphaeromias chilensis (Ingram \& Macfie, 1931); 20-22, Austrosphaeromias setosa sp. nov. 17, 20, female abdominal segments $8-10 ; 18,21$, aedeagi; 19,22 , parameres. Scale bars: $0.05 \mathrm{~mm}$. 
9-13 lighter brown; flagellomeres 2-8 vasiform, moderately short, flagellomeres 9-13 elongate; antennal ratio 1.26-1.45 $(1.34, \mathrm{n}=10)$. Palpus dark brown; segment 3 shorter than 4-5, with 3-7 mesal capitate sensilla; palpal ratio 3.27-4.32 (3.61, $n=10)$. Mandible with 7-8 large coarse inner teeth.

Thorax (Fig. 10) dark brown. Scutum with small anterior tubercle, sparsely covered with small setae, with four stout supralar setae; scutellum with 4-6 stout setae and several smaller setae. Legs mostly brown, fore-, mid femora yellowish brown, femorotibial joints dark brown; tarsomeres brown, proximal $2 / 3$ of tarsomere 1 of fore leg lighter brown; fore femur greatly swollen, 3.00-4.00x $(3.55, \mathrm{n}=10)$ longer than broad with 15-24 ventral spines; palisade setae in two rows on tarsomeres 1-2 of hind leg, in one row on tarsomere 1 of midleg; tarsomeres 5 (Fig. 11) without ventral stout setae. Wing (Fig. 12) membrane lightly infuscated, anterior veins brown, posterior veins lighter brown; M sessile, the distance between $r-m$ crossvein and base of vein $\mathrm{M}_{2}$ twice as long as $\mathrm{r}-\mathrm{m} ; 2^{\text {nd }}$ radial cell $1.69-2.77 \times(2.15, \mathrm{n}=10)$ longer than first cell; wing length 2.06-2.54 mm (2.31, $\mathrm{n}=10)$, breadth 0.72-0.84 mm (0.79, $\mathrm{n}=10)$; costal ratio $0.75-0.79(0.77, \mathrm{n}=10)$. Halter dark brown.

Abdomen dark brown. Genitalia as in Figs 13, 20. Sternite 8 with anterocentral pear-shaped group of 24-37 stout setae; sternite 9 moderately sclerotized with pair of slender, nearly straight, anteromesally directed arms; sternite 10 moderately long, deeply heart-shaped with 6-7 pairs of large setae. Two ovoid, slightly unequal spermathecae (Fig. 13) with short necks, measuring 80-90 $(91, \mathrm{n}=8)$ by $54-70 \mu(65, \mathrm{n}=8)$, and $60-86(77, \mathrm{n}=8)$ by $50-64 \mu(54, \mathrm{n}=8)$; and a small rudimentary $3^{\text {rd }}$ spermatheca that is well developed in one specimen.

Male. Similar to female, but smaller with the following notable sexual differences: head (Fig. 14) with antennal flagellum relatively short, flagellomeres 1-8 shortest, 9-10 longer, 11-13 elongate; flagellomere 11 $1.46-1.65 x(1.57, \mathrm{n}=5)$ longer than 10 ; antennal ratio (11$13 / 1-10)$ 0.57-0.75 (0.70, n=5). Wing (Fig. 15) membrane slightly infuscated, posterior veins light brown; $2^{\text {nd }}$ radial cell 1.00-1.64x $(1.40, \mathrm{n}=5)$ longer than first cell; wing length 1.64-1.92 mm (1.73, $\mathrm{n}=5)$, breadth 0.56-0.62 mm (0.59, $\mathrm{n}=5)$; costal ratio $0.69-0.73(0.71, \mathrm{n}=5)$. Genitalia (Fig. 16): tergite 9 moderately short, narrowing slightly distally, posterior margin notched, extending considerably below apices of gonocoxites; cerci elongate, not reaching distal level of gonocoxites, with 2 pairs of setae, one pair elongate, 2nd pair shorter; sternite 9 moderately short with deep, rounded, posteromedian excavation, ventral membrane spiculate. Gonocoxite straight, twice as long as broad with a large pointed anteromesal protuberance; gonostylus 0.66 length of gonocoxite, proximal 0.8 nearly straight, distal 0.2 greatly curved mesally with slender pointed tip. Parameres (Fig. 22) closely approximated fused for most of mid-portion; basal apodeme broad, lightly sclerotized, slightly recurved; distal portions straight on proximal $2 / 3$, distal $1 / 3$ expanded, closely approximated, apices rounded. Aedeagus (Fig. 21) triangular, slightly longer than broad, basal arm and proximal 0.5 of lateral margins heavily sclerotized; basal arms stout, straight or slightly recurved; basal arch extending 0.4 of total length; distal portion lightly sclerotized, gradually narrowed distally with small crescent-shaped tip, anterior margin deeply convex.

Distribution. Argentina (Nahuel Huapi and Puelo National Parks, northern Santa Cruz province); Chile (General Carrera province).

Types. Holotype $\widehat{\jmath}$, ARGENTINA, DWN-14/3, Parque Nacional Nahuel Huapi: arroyo Ñireco, 41 $11^{\prime}$ '51' $\mathrm{S}$, 71'19'40.5'W, 962 m, 23.I-13.II.2007, A. Garre-F. Montes de Oca, Malaise trap (MLPA); allotype $q$, same data as holotype except: río Manso Medio, 41 ${ }^{\circ} 14^{\prime} 8.1^{\prime \prime} \mathrm{S}$, 7146'58.5”W, 845 m, 7.II-2.III.2007, A. Garre-F. Montes de Oca, Malaise trap (MLPA). Other paratypes, $11 \hat{\jmath}, 18 \bigcirc$, as follows: same data as holotype, $9 \hat{\jmath}, 70(5 \hat{\jmath}, 3 \propto$ in MLPA; $\hat{\jmath}, q$ in USNM; $\hat{\sigma}, q$ in BMNH; $\hat{\sigma}, q$ in CNCI, $\hat{\jmath}$, i in FSCA); same data as holotype except: lago Villarino, 5.XII.1992, G. Spinelli, sweep net, 39 (MLPA); same data as holotype except: lago Gutiérrez, 20.I.2006, W. Grogan-G. Spinelli, sweep net, ふ̋ (MLPA); same data as holotype except: lago Steffen, 30.XI.1999, P. Marino, sweep net, 5 (MLPA). Parque Nacional Puelo: margen E lago Puelo, 24.II.1994, G. Spinelli, sweep net, + (MLPA). Santa Cruz: valle río Pinturas, 5.XII.1996, G. Spinelli, Malaise trap, ô (MLPA); same data except: at light, .q (MLPA). CHILE, General Carrera: Chile Chico, 24-31. XII.1960, L. Peña, q (MLPA).

Etymology. The species name is a reference to the conspicuous group of stout setae on sternite 9 of females of this new species.

Taxonomic discussion. Females of this new species are readily distinguished from its congeners by the tarsomeres 5 that lack ventral stout setae and by the conspicuous pear-shaped group of 24-37 stout setae on sternite 8 . The male antenna is also very distinctive, with the flagellomeres 11-13 distinctly shorter than in males of A. apricans and A. chilensis, the only other two species with known males.

Acknowledgements. This is a contribution of the Darwin Inititative project: "Capacity building for biodiversity studies of freshwater insects in Argentina”. We extend our gratitude to Nélida Caligaris for technical assistance.

\section{REFERENCES}

Borkent, A. 2014. World species of biting midges (Diptera: Ceratopogonidae). Available at $<\mathrm{http} / / \mathrm{wwx}$.inhs.illinois.edu/ files/9913/9144/3328/CeratopogonidaeCatalog.pdf > . Accessed on October 2014.

Borkent, A. \& Sinelui, G. R. 2000. Catalog of the new world biting midges South of The United States of America (Diptera: Ceratopogonidae). Contributions on Entomology, International 4(1):1-107.

. 2007. Neotropical Ceratopogonidae (Diptera: Insecta). In: ADIS, J.; Arias, J. R.; Rueda-Delgado, G. \& Wantzen, K. M. eds. Aquatic Biodiversity in Latin America (ABLA). Vol. 4. Sofia-Moscow, Pensoft. 198p.

Borkent, A. \& Wirth, W. W. 1997. World species of biting midges (Diptera: Ceratopogonidae). Bulletin of the American Museum of Natural History 233:1-127. 
Brown, B. V.; Borkent, A.; Cumming, J. M.; Wood, D. M.; Woodley, N. E. \& Zumbado, M. A. eds. 2009. Manual of Central American Diptera. Vol. 1. Ottawa, National Research Council of Canada, Research Press. 714p.

Grogan, W. L., JR. \& Wirth, W. W. 1979. The North American predaceous midges of the genus Palpomyia Meigen midges (Diptera: Ceratopogonidae). Memoirs of the Entomological Society of Washington 8:1-125.

Ingram, A. \& Macfie, J. W. S. 1931. Ceratopogonidae. In: Diptera of Patagonia and South Chile, based mainly on material in the British Museum (Natural History). Part II. Fasc. 4. Nematocera. London, Printed by order of the Trustees, p. 155-232.
Spineldi, G. R. 1996. A new genus of the tribe Sphaeromiini from subantarctic Argentina and Chile related to Mackerrasomyia Debenham (Diptera: Ceratopogonidae). Memoirs of the Entomological Society of Washington 18: 224-229.

Spinelli, G. R., Grogan, W. L., JR. \& Ronderos, M. M. 2009. A revision of the Patagonian predaceous midges of the genus Palpomyia Meigen (Diptera: Ceratopogonidae). Insect Systematics and Evolution 40:43-70.

Wirth, W. W. 1974. Family Ceratopogonidae. In: Papavero, N. ed. A catalogue of the Diptera of the Americas south of the United States, Fasc. 14. São Paulo, Departamento de Zoologia, Secretaria de Agricultura. 89p. 